\title{
THE PATRISTIC ROOTS OF SATISFACTION ATONEMENT THEORIES \\ DiD THE CHURCH FATHERS AFFIRM ONLY CHRISTUS \\ VICTOR?
}

James David Meyer

(jmeyer14@my.whitworth.edu)

\begin{abstract}
Summary
In his work Christus Victor, Gustaf Aulén argued that Anselm of Canterbury's account of the atonement was foreign to ancient Christian belief. In particular, Aulén argued that Anselm diverged from the original understanding of the doctrine as presented by the church fathers. Aulén argued that the Eastern church rightly endorsed a model of the atonement that he called the 'classic view', while Anselm in the West later wrongly developed a theory of satisfaction that Aulén called the 'Latin' view. This critique, by extension, applies to other 'Anselmic' theories of atonement such as penal substitution that, like Anselm's, also affirm that Christ's death in some way satisfied God's requirements in response to human sin. Patristic literature shows, however, that Aulén's conclusion is more imposition than exposition. Fathers from both East and West commonly advanced theories that comport well with what Aulén called the Latin view alongside Christus Victor.
\end{abstract}

\section{Introduction}

The 'satisfaction' theory of the atonement provides a specific explanation of why Christ had to die and what his death accomplished. Scholars often associate this view with Anselm of Canterbury because his Cur Deus Homo provides one of the most systematic presentations of this view. In its essence, satisfaction theory holds that Jesus's innocent death on behalf of sinful human beings presented something to God as atonement for human sin; it satisfied God's just requirement of 
judgement in response to sin. In other words, Christ accomplished as a man something that sinful men and women could not accomplish for themselves and without which reconciliation to God was impossible.

Those who adhere to this broad 'Anselmic' tradition express Christ's accomplishments using a variety of terms - substitution, propitiation, representation, payment of debt, and others. One version of this tradition of interpretation is known as 'penal substitutionary atonement'. It advances a particular understanding of how Christ made restitution for $\sin$ - namely, that he bore the punishment for sin that God required. ${ }^{1}$

Increasingly, this type of atonement theory, including penal substitution, is under attack. A common argument against it challenges its pedigree in the early history of the church. In particular, critics claim that Anselm's view, and that of others who hold that Christ atoned for sin by presenting himself as a blameless offering to God, diverge from what the early church believed about the cross. For instance, churchman Giles Fraser characterises penal substitution as a 'nasty perversion of the Easter story' and asserts that 'it was dreamt up by Anselm in the 11th century and later added to by Calvin'.2

Fraser's statements propagate the misconception that Anselm's satisfaction theory is identical with penal substitution specifically. There are in fact many types of the wider Anselmian approach, including penal substitution. Though not all are identical to Anselm's theory of the atonement, all share the common concept of some sort of divine satisfaction. ${ }^{3}$ Nevertheless, historically based arguments against the legitimacy of satisfaction theories, including penal substitution, have gained momentum in recent years. As Peter Ensor observes, 'it has recently been asserted that the theory of penal substitutionary atonement is a relatively modern doctrine, going back no further than the Reformation'. ${ }^{4}$

1 Joshua McNall distils all forms of penal substitution into three essential elements: (1) Punishment - human sin is the offence for which Christ pays the penalty; (2) Substitution - Christ bears the penalty instead of us; (3) Divine Sanction - Christ bore the penalty in some way sanctioned by God the Father, the judicial authority of atonement. Joshua McNall, The Mosaic of Atonement (Grand Rapids: Zondervan, 2019): 101-107.

2 Giles Fraser, 'Cross Purposes', The Guardian (4 April 2007) $<$ http://www.theguardian.com/commentisfree/2007/apr/04/christrecrucified $>$ [accessed 9 September 2020].

3 Michael Ovey, 'Appropriating Aulén? Employing Christus Victor Models of the Atonement', Churchman 124.4 (2010): 297-330, esp. 299.

4 Peter Ensor, 'Justin Martyr and Penal Substitutionary Atonement', EvQ 83.3 (2011): 217-32, esp. 217. 
In his work Christus Victor (1931), Gustaf Aulén developed the argument that satisfaction theories, which he attributes to Anselm, were indeed foreign to ancient Christian belief. As Michael Ovey observed, though, his arguments are most commonly applied to refute penal substitution, one expression of the Anselmic tradition: 'Aulén's argument is significant in our current debates because it offers ... reasons to deny that penal substitution is a legitimate picture of the Cross. ${ }^{5}$

Aulén argued that an essential split took place between East and West in Christian history regarding understandings of the cross. In his view, the East rightly endorsed what he calls the 'classic view' of atonement, or 'Christus Victor'. According to Aulén, Christ as a man did not 'make an offering or payment to satisfy God's justice', ${ }^{6}$ but as God he achieved victory over Satan, sin, and death, freeing human beings from their power. As he explained:

The Word of God, who is God Himself, has entered in under the conditions of sin and death, to take up the conflict with the powers of evil and carry it through to the decisive victory. This has brought to pass a new relation between God and the world; atonement has been made. ${ }^{7}$

On the other hand, Aulén claims that the West later developed a mistaken alternative to the classic view, which he calls the 'Latin' view - his synonym for Anselm's satisfaction theory.

To argue for the classic view over and against the Latin view - though these labels presuppose his conclusion somewhat - Aulén relies heavily on sources from the patristic period (in this article understood as the first five centuries AD). He asserts that the Fathers unanimously endorsed Christus Victor, while conversely the essential elements of the Latin view are entirely absent in the East, and absent in all but a few outliers in the West. $^{8}$ 'There can be no dispute', Aulén says, 'that [the classic view] is the dominant idea of the atonement throughout the early church period ... it was, in fact, the ruling idea of the atonement for the first thousand years of Christian history. ${ }^{9}$ After that time, he continues,

5 Ovey, 'Appropriating Aulen?', 298.

6 Gustaf Aulén, Christus Victor: An Historical Study of the Three Main Types of the Idea of Atonement (London: SPCK, 1931; repr. Eugene: Wipf \& Stock, 2003): 98.

7 Aulén, Christus Victor, 32.

8 The only exceptions that Aulén acknowledges are Western Fathers; he insists upon the homogeneity of the Greek Fathers. He argues that the 'first traces' of a view resembling Anselm's come from Tertullian, and that Cyprian after him developed it further (Aulén, Christus Victor, 38-39).

9 Aulén, Christus Victor, 6. 
Anselm constructed the Latin view, which permanently altered beliefs about the cross in Western Christendom. Therefore, he dismisses Latin views of the atonement as a doctrinal 'side-track' ${ }^{10}$ in Christian history.

The majority of Aulén's critics have developed scriptural and theological objections to his thesis, but do not concentrate on his historical claims. ${ }^{11}$ In his own critique, Ovey admits that space precluded him from 'dealing with early patristic candidates for teaching penal substitution as well as other accounts of the Cross', ${ }^{12}$ but in doing so suggests the need for such a study to augment existing critiques.

This article aims to provide such a historical analysis of Aulén's claims, assessing whether he represents the Fathers accurately. It will acknowledge that the Fathers affirmed that Christ achieved victory by freeing humankind from bondage to Satan, sin, and death. Nevertheless, it will argue that the Fathers did not affirm this view to the exclusion of, or in opposition to, views of the Latin type. Instead, they affirmed both views, namely, that (1) Christ triumphed over Satan, sin, and death, and (2) he did so in part by satisfying the requirements of God in response to $\sin$.

Since Aulén critiques Anselm directly, this article will demonstrate that the broader Anselmic tradition of satisfaction theories has widespread roots in the patristic era. In so doing, it will show by extension that Aulén's historical critique of satisfaction theories also fails as a critique of penal substitution. Indeed, the basis of Aulén's critique of Anselm is precisely Aulén's rejection of the notion of divine satisfaction, and this concept is common to all 'Latin' theories of atonement including penal substitution. Moreover, while all of the Fathers examined in this article affirm some form of the Latin view, some also articulate the essential logic of penal substitution, thus further challenging Aulén's historical claims. Indeed, I will show that a close reading of the Fathers does not justify rejecting either Anselm's general theory of satisfaction or the specific version of it known as penal substitution.

\footnotetext{
10 Aulén, Christus Victor, 14.

11 In 'Appropriating Aulén?' Ovey argues that in Scripture the concept of God's justice underlies that of his victory, and this vital relationship is unaccounted for in Aulén's framework, obscuring the very nature of the victory Christ achieved. Others have argued that Aulén's doctrine of the incarnation diverges from the orthodox doctrine defined at the Council of Chalcedon.

12 Ovey, 'Appropriating Aulen?', 324.
} 


\section{Gustaf Aulén and the Classic View}

What Aulén calls the 'classic view' does find widespread expression in patristic discussions of the atonement. Aulén demonstrates this using Irenaeus (AD 140-202) as his primary witness, and then shows with several later Fathers 'how repeatedly and how powerfully [Irenaeus'] central ideas recur in their teaching'. ${ }^{13}$

Aulén first explains that Irenaeus emphasises the incarnation when he speaks about Christ's victory. For example, Irenaeus asks this in Against Heresies: 'For what purpose did Christ come down from heaven?'14 To answer, Aulén cites a characteristic text in that same work: 'That he might destroy sin, overcome death, and give life to man. ${ }^{15}$ This linkage is indeed common in Irenaeus and other Fathers. ${ }^{16}$ His twofold emphasis on incarnation and atonement is significant, Aulén argues, because it demonstrates the belief that 'Christ came down from heaven because no power other than that of God himself was able to accomplish the work that was to be done. ${ }^{17}$ Thus, he argues that Irenaeus and the Fathers after him invariably represent 'the work of atonement or reconciliation as from first to last a work of God himself, a continuous divine work'. ${ }^{18}$

Aulén uses this conclusion to argue that there is little evidence in patristic writings of the idea that Christ came to satisfy the just requirement of God in response to $\sin$ - what he calls the Latin view. This view, he says, has a different structure, in which 'the act of atonement has indeed its origin in God's will, but is, in its carrying-out, an offering made to God by Christ as man and on man's behalf ... a discontinuous divine work'. ${ }^{19} \mathrm{He}$ then concludes that each church father

13 Aulén, Christus Victor, 35.

14 Irenaeus, Against Heresies 2.14.7, in Aulén, Christus Victor, 19.

15 Irenaeus, Against Heresies, 3.18.7, in Aulén, Christus Victor, 19.

16 'The reason God is in the flesh is to kill the death that lurks there. As diseases are cured by medicines assimilated by the body ... so death, which held sway over human nature, is done away with by the coming of God.' Basil the Great, Homily on Christ's Ancestry 2.6 (ACCS NT 4A:42).

17 Aulén, Christus Victor, 33.

18 Aulén, Christus Victor, 5.

${ }^{19}$ Aulén, Christus Victor, 5. This supposed 'discontinuity' is how Aulén typifies all forms of the Latin view and it is why his argument is also relevant in contemporary discussion about the legitimacy of penal substitution specifically; all varieties of the view are ahistorical according to his account of the Fathers. Ovey observes that in Aulén's estimation, 'discontinuity' is a mark against the theory because 'such payment made as a man undermines the message of grace and re-instates, it seems, merit and law' (Ovey, 'Appropriating Aulen?', 304). Ovey rightly challenges that this is a fair representation of Anselm, but that discussion is beyond the scope of this article. 
he examines expresses 'no thought of a human offering made to God from man's side'. ${ }^{20}$ In his survey of patristic authors, he finds that no Fathers in the East, and only Cyprian in the West, articulate the idea that Christ's human nature was also efficacious for atonement by presenting something to God. Therefore, he argues that the Latin view is not grounded in the patristic era.

Aulén even extends his argument to a few patristic passages that employ imagery commonly used in the Anselmic tradition, such as 'sacrifice' and 'satisfaction'. He argues that these words have misleading connotations to modern ears - that they actually express the classic view. As he explains, 'Nothing is more common than to find points which really belong to the classic idea treated as if they were anticipations of the theory of Anselm.'21 To interpret these words as exclusively supporting Christus Victor, he commandeers terms that naturally comport well with Anselm's view and redefines them contrary to their obvious meaning. For example, he addresses an excerpt from Athanasius that describes Christ's death as a 'vicarious sacrifice' that 'removed death from all His brethren'. ${ }^{22}$ He claims that readers are mistaken to assume that this is an anticipation of Anselm's theory - Athanasius did not mean that Christ as man offered a sacrifice to God for human sin because 'the debt is regarded as paid primarily to death', ${ }^{23}$ not to God. Therefore, Aulén argues that

Athanasius is in no way forsaking the classic point of view; the payment of the debt is [instead] God's own act ... least of all is it true to say that we have here anything like a rational theory of the Latin type. ${ }^{24}$

Aulén therefore justifies his conclusion by asserting at every turn that the Fathers did not regard atonement as something that was made by Christ, as man, and to God. As he says, 'Even when the suffering which Christ endured is treated as the endurance of the punishment which men deserved ... this is the accomplishment of God's own work' while 'the typically Latin view of the atonement always regards the sacrifice as offered by man to God' ${ }^{25}$ Therefore, he says, 'when [the Fathers say that] Christ suffers the punishment involved in God's judgment on sin', it

\footnotetext{
20 Aulén, Christus Victor, 33.

21 Aulén, Christus Victor, 39.

22 Aulén, Christus Victor, 56-57.

23 Aulén, Christus Victor, 56.

24 Aulén, Christus Victor, 56-57.

25 Aulén, Christus Victor, 57.
} 
must simply be another way of saying that 'the tyrants are overcome', because they regard these tyrants as 'from another point of view, the executants of God's judgment' ${ }^{26}$ Therefore, when God deals with the hostile powers he is, in effect, dealing with himself as well, becoming reconciled with the world. As he puts it: 'the victory over the hostile powers brings to pass a new relation ... between God and the world' ${ }^{27}$

Aulén refers to this phenomenon - in which terms that appear to describe the Anselmic approach actually express the Christus Victor view - as the 'double-sidedness' of the classic view. His judgement about this leads him to conclude that, despite appearances, 'there are not different theories of the atonement in the Fathers, but only variant expressions of one and the same basic idea'. ${ }^{28}$

The passages from Irenaeus and later Fathers that explicitly support Christus Victor, upon which Aulén focuses most of his attention, are clear. But again, Aulén uses those select passages to justify a more expansive claim, namely, that 'there are not different theories of the atonement in the Fathers'. A careful examination of patristic literature shows, however, that Aulén's thesis is more imposition than exposition. There are, in fact, plentiful examples of patristic writers who thought that Christ satisfied God's justice on the cross, and that it was precisely his suffering as a man, indeed a sinless man, that rendered his work efficacious. Therefore, Aulén's classic view is not descriptive of all views of the Church Fathers. Indeed, Fathers from both East and West articulated several interpretations of the atonement, and prominent among them were views that establish the essential elements of satisfaction theory long before Anselm articulated it.

To demonstrate this, the following discussion provides an exposition of fifteen patristic writers spanning the first five centuries of Christian history. In a manner consistent with Anselmian views, each Father articulates the efficacy, and necessity, of Christ's death as a man to atone for $\sin$ - that his death presented something to God without which reconciliation was impossible, such as payment of debt or divinely sanctioned punishment. These witnesses cumulatively demonstrate that

\footnotetext{
26 Aulén, Christus Victor, 56-57.

27 Aulén, Christus Victor, 5.

28 Aulén, Christus Victor, 37. The above summary incorporates Aulén's conclusions on the Anselmic tradition, which is the subject I wish to discuss. This is not an exhaustive review of Christus Victor.
} 
this type of view was common and accepted from the nascence of Christianity onward.

\section{The Patristic Roots of Satisfaction Theories of Atonement}

\subsection{First Century}

\section{a. Epistle of Barnabas}

[The] Lord endured the deliverance of his flesh to corruption, so that we might be cleansed by the forgiveness of sins, that is, by his sprinkled blood. For the scripture concerning him relates partly to Israel and partly to us, and speaks as follows: 'He was wounded because of our transgressions, and has been afflicted because of our sins; by his wounds we were healed. Like a sheep he was led to slaughter, and like a lamb he was silent before his shearer.' (Barn. 5:1-2) ${ }^{29}$

Explanations of Christ's atoning work such as this one predate the writings of Irenaeus, the earliest Father that Aulén cites. This excerpt from the Epistle of Barnabas dates between AD 70 and 130. It is evidence that Barnabas understood Christ's work as the fulfilment of both the typology expressed in Israel's sacrificial system and the prophecy of Israel's Suffering Servant in Isaiah 53. First, with respect to the typology, 'sprinkled blood' alludes to the Day of Atonement rites in Leviticus 16. Moreover, later in the Epistle (chapters 7-8) he explains that the scapegoat and heifer were types fulfilled in Jesus. The concept of sacrifice is hotly contested in contemporary scholarship, but at least the Day of Atonement rites give the clear sense that the animals, offered by the people to God for their sins, were sin-bearing substitutes. Moreover, Barnabas explains that these Scriptures pertain not just to ancient Israel but also to the predicament facing all people - human sin necessitates a human offering to God for reconciliation to happen. This is a distinguishing tenet of the Anselmic tradition, and the explanation in Barnabas of the typology strongly suggests that this is what he perceived was fulfilled by Christ on the cross.

Secondly, Barnabas identifies Jesus as the prophesied Suffering Servant who would create peace with God by enduring the punishment

29 Quotations from Barnabas, 1 Clement, and Diognetus are taken from Michael W. Holmes, ed., The Apostolic Fathers: Greek Texts and English Translations $\left(3^{\text {rd }}\right.$ edn; Grand Rapids: Baker Academic, 2007). 
for Israel's sins (Isa. 53:5). Because Barnabas does not use the keyword 'punishment' from Isaiah 53:5 (מוֹסָר / musar) in his quotation, it is not clear that his view constitutes penal substitution specifically. Nevertheless, the necessity of Christ's humanity as a satisfactory substitute, which is characteristic of all atonement theories of the Latin type, comes through clearly in the phrases he cites from Isaiah (i.e. 'He was wounded because of our transgressions' and 'has been afflicted because of our sins'). Moreover, the author explains the applicability of Old Testament typology and prophecy without any reference to a victorious conflict with the powers of darkness, making it implausible that this is reducible to an expression of Aulén's classic view.

\section{b. First Epistle of Clement}

In love all the elect of God were made perfect; without love nothing is pleasing to God ... Because of the love that he had for us, Jesus Christ our Lord, in accordance with God's will, gave his blood for us, and his flesh for our flesh, and his life for our lives. (1 Clem. 49:5-6)

1 Clement was composed in the last decade of the first century. Like Barnabas, Clement identifies Christ as the fulfilment of the Suffering Servant prophecy. Chapter 16 of the epistle describes Christ's work by closely paraphrasing Isaiah 53, in which Isaiah affirms that the Suffering Servant died 'for our transgressions' and 'for our sins' (Isa. 53:5). In context, therefore, Clement's discussion of Christ '[giving] his blood for $u s$ ' seems to affirm that Christ offered himself in place of human beings in order to make them 'pleasing' in God's sight. Christ's love, he says, makes us acceptable to God because his love motivated him to die on our behalf. Clement's logic strongly indicates that he understands Christ's death as an acceptable offering made to God. This is a significant element of the Anselmic view. ${ }^{30}$

Moreover, Clement uses the much-discussed Greek phrase vi $\pi \dot{\varepsilon} \rho \dot{\eta} \mu \tilde{\omega} v$ (hyper hèmōn), which means 'on behalf of us' and which appears frequently in New Testament (e.g. 2 Cor. 5:21) and patristic writings regarding Christ's death. The preposition vi $\pi \dot{\varepsilon} \rho$ implies the idea of

\footnotetext{
30 Recall also that Aulen differentiates between the will of God and a work of God - he acknowledges that even views of the 'Latin' type regard the cross as having 'its origin in God's will' (Aulén, Christus Victor, 5). Indeed, many of the Fathers examined in this article, such as Clement here, explain that Christ died in accordance 'with God's will'. And as Aulén himself acknowledges, this is not evidence that they are describing the classic view. The divine initiative is characteristic of satisfaction theories as well; atonement can be simultaneously willed by God and offered to God.
} 
vicarious participation, and therefore the passages in which it appears affirm that Christ died the death that should have been ours in order to reconcile us to God. Again, in this passage - and most others where vi $\pi \dot{\varepsilon} \rho$ $\dot{\eta} \mu \tilde{\omega} v / \dot{\nu} \mu \tilde{\omega} v$ (hyper hēmōn/hymōn) appears - the imagery of a victorious conflict with the hostile powers is absent. ${ }^{31}$

\subsection{Second Century}

\section{a. Epistle to Diognetus}

[When] our unrighteousness was fulfilled, and it had been made perfectly clear its wages - punishment and death - were to be expected, then the season arrived during which God had decided to reveal at last his goodness and power ... in his mercy he took upon himself our sins; he himself gave up his own Son as a ransom for us, the holy one for the lawless, the guiltless for the guilty, the just for the unjust ... For what else but his righteousness could have covered our sins? In whom was it possible for us, the lawless and ungodly, to be justified, except in the Son of God alone? $\mathrm{O}$ the sweet exchange, $\mathrm{O}$ the incomprehensible work of God, $\mathrm{O}$ the unexpected blessings, that the sinfulness of many should be hidden in one righteous person, while the righteousness of one should justify many sinners! (Diogn. 9:2-5)

The Epistle to Diognetus is an apologetic text likely from the mid-second century. In it the author describes Christ's unique sufficiency to 'ransom' sinful humanity. Ransom implies payment; it is at least clear that the author views the cross as Christ's payment to atone for human sin. Yet Aulén claims that the idea of ransom in the Fathers cannot be categorised as an expression of the Latin view. He says that the early church typically regarded ransom as 'a semi-legal transaction' 32 between God and Satan: 'the price of the life of Christ, paid as ransom for men, is commonly regarded as paid to the devil ... [the idea] was firmly established in the early church, and it constantly recurs in the Fathers. ${ }^{33}$ Therefore, the image of ransom does not fit with the Latin tradition because it describes God as the sole active agent in achieving reconciliation through overcoming evil; Christ's humanity has no necessary role.

Diognetus, however, refutes that generalisation of ransom imagery. It also predates Aulén's exemplars of ransom imagery, Gregory of Nyssa and John of Damascus. First, the author plainly states that the 'exchange' on the cross was effective because of Christ's sinless human nature; the

\footnotetext{
31 Harald Riesenfeld, 'hyper', TDNT 8: 507-16.

32 Aulén, Christus Victor, 53.

33 Aulén, Christus Victor, 49-50.
} 
sin of humanity was 'hidden in one righteous person' who bore 'its wages - punishment and death'. By emphasising that Christ represented all people in order to 'justify' them, and that he did so by enduring the divinely sanctioned punishment for sin, Diognetus demonstrates a general agreement with later Anselmic views, as well as the essential elements of penal substitution specifically. At the very least, his view is not plausibly reducible to the classic view as defined by Aulén. This is further substantiated by the absence of Satan, and any idea of a transaction with him, in this quotation or its surrounding context. Later Fathers indeed interpreted ransom imagery with reference to God's victory over Satan. Yet Diognetus - in one of the earliest extant teachings about ransom - instead appears to articulate a view that aligns with Anselm's, wherein Christ's death as a man satisfies God's requirements regarding sin.

\section{b. Irenaeus}

Christ became 'the Mediator between God and men; propitiating indeed for us the Father against whom we had sinned, and cancelling our disobedience by his own obedience; conferring also upon us the gift of communion with, and subjection to, our Maker.' 34

For if no one can forgive sins but God alone, while the Lord remitted them and healed men, it is plain that He was Himself the Word of God made the Son of man, receiving from the Father the power of remission of sins; since he was man, and since he was God, in order that since as man He suffered for us, so as God he might have compassion on us, and forgive us our debts, in which we were made debtors to our God and Creator. ${ }^{35}$

Irenaeus is Aulén's primary authority in support of the classic view, and yet he also articulates the distinctive tenets of the Latin view. In the first excerpt, Irenaeus teaches that Christ did something on behalf of sinful people which they could not do for themselves, 'propitiating the Father' by his death. The concept of propitiation, from the Latin propitiatio, refers to turning away divine wrath by a gift or sacrifice. ${ }^{36}$ This alone

\footnotetext{
34 Irenaeus, Against Heresies 5.17.1 (ANF 1:544).

35 Irenaeus, Against Heresies 5.17.3 (ANF 1:545).

36 See Leon Morris, 'Propitiate, Propitiation' in The International Standard Bible Encyclopedia, vol. 3, ed. Geoffrey W. Bromiley (Grand Rapids: Eerdmans, 1986): 1004. Some, like C. H. Dodd, dispute this meaning, claiming that the Latin propitiatio does not adequately render the underlying Greek and Hebrew words hilastērion (i $\lambda \alpha \sigma \tau \eta \dot{\rho} \rho ı v$ ) and kipper (כִִּ (כ). He concludes it more nearly means 'expiation', a sacrifice that annuls sin without reference to God's wrath. C. H. Dodd, The Epistle of Paul to the Romans (London: Hodder \& Stoughton, 1932): 21. McNall argues, however, that Irenaeus' meaning in this passage only makes sense in the traditional meaning: 'when one speaks
} 
suggests that Irenaeus maintained more than one interpretation of the atonement, as he clearly regards God the Father as the object of propitiation. Yet Aulén insists that Irenaeus advanced only the classic view because he regarded Christ's accomplishments as God's own act.

Aulén also fails to address Irenaean texts like the second excerpt above, which establish the particular efficacy of Christ's humanity to atonement: 'as man he suffered for us'. This concept is not uncommon in his writings. ${ }^{37}$ Ovey likewise observes, 'Continuity is lost, argues Aulén, because Christ offers as man. Yet Irenaeus's account of Recapitulation [in which Christ's obedience annuls our disobedience] stresses that Christ obeys as man. ${ }^{38}$

The evidence from Irenaeus that Aulén overlooks, then, demonstrates that Irenaeus held a view consistent with Anselm's general approach that Christ's innocent death as a man accomplished a host of benefits that we could not accomplish ourselves, including 'propitiating the Father'. This is not reducible to the classic view.

\section{c. Justin Martyr}

For the whole human race will be found under a curse. For it is written in the law of Moses, 'Cursed is everyone that continueth not in all things that are written in the book of the law to do them.' And no one has accurately done all ... If, then, the Father of all wished His Christ for the whole human family to take upon Him the curses of all, knowing that, after $\mathrm{He}$ had been crucified and was dead, He would raise him up, why do you argue about Him, who submitted to suffer these things according to the Father's will, as if he were accursed, and do not rather bewail yourselves? ${ }^{39}$

Galatians 3:10-13, and its underlying quotations from Deuteronomy, recur as centrally important texts in patristic teachings on atonement. The above excerpt from Justin's Dialogue with Trypho presents one of the earliest explanations of atonement with that scriptural backdrop in mind. Justin imitates Galatians 3:10 by quoting Deuteronomy 27:26 to describe the human predicament and then continues to explain that Christ took 'upon him[self] the curses of all', which seems to be a clear allusion to Galatians 3:13. A closer examination of how Justin uses these texts

of expiation, the object is usually sin, while the object of propitiation is God or divine wrath ... Irenaeus clearly views God the Father as the object of the action'. McNall, Mosaic of Atonement, 111.

37 See On the Apostolic Preaching 31 or Against Heresies 4.8.2.

38 Ovey, 'Appropriating Aulen?', 314.

39 Justin Martyr, Dialogue with Trypho 94-95 (ANF 1:247). 
reveals an understanding of the cross consistent with a satisfaction-type view.

Since 'no one has accurately done all', he argues, all humanity has become liable to death as punishment - this comprises the curse. Indeed, elsewhere in the Dialogue Justin confirms that he understands the curse as punishment for sin:

For God, wishing both angels and men, who were endowed with freewill ... to do whatever he had strengthened each to do, made them so, that if they chose the things acceptable to himself, he would keep them free from death and from punishment; but that if they did evil, he would punish each as he sees fit. ${ }^{40}$

God's Messiah, then, came on behalf of 'the whole human family to take upon him[self] the curses of all' and free them from the punishment they had incurred. This work brings restoration, as Justin concludes later that Jesus died 'in order that by his stripes the human race might be healed'. ${ }^{41}$

In this explanation, Justin emphasises that the Messiah was a true member of the 'human family', and it is precisely this that made his death effective for humankind. He articulates the view that Christ suffered divinely sanctioned punishment in our place and for our healing. Therefore, Justin's view cannot plausibly be categorised as Aulén's classic view. Indeed, the powers of darkness, and any notion of a victorious conflict with them, are absent in this quotation and its surrounding context. Instead, Justin's view expresses the essential elements of the Anselmic view, whereby God's required judgement of human $\sin$ is satisfied by a human payment in the person of Christ. Moreover, Justin also articulates the essential logic, though not a full theory, of penal substitution specifically. Peter Ensor concludes the same in his summation of Justin's view: 'Christ bore our curse, the penalty for our sin, that we might not have to bear it ourselves. This means that Christ died in our place, that we might live, which is the essence of the penal substitutionary understanding of the atonement. ${ }^{42}$ In addition to

40 Justin, Dial. 88 (ANF 1:243).

41 Justin, Dial. 95 (ANF 1:247).

42 Ensor, 'Justin Martyr', 225. McNall disagrees with the claim that Justin articulated the logic of penal substitution (McNall, Mosaic of Atonement, 108-109). McNall doubts that, for Justin, the curse that Christ bears is the same as that which hung over humanity due to $\sin$. He notes that elsewhere Justin says that "though a curse lies in the law against persons who are crucified, yet no curse lies on the Christ of God' (Dial. 94). Therefore, when Justin declares that Jesus took 'upon himself the curses of all', McNall asserts that he likely means something else - perhaps that Christ endured the curses directed at him by those who disbelieved him. This, however, does not match the broader context of 
Justin, it could be argued that several other Fathers interpret this Pauline passage in a similar fashion. ${ }^{43}$

\subsection{Third Century}

\section{a. Origen}

God has manifested his righteousness and given Christ to be our redemption. He has made him our propitiator ... For God is just, and therefore he cannot justify the unjust. Therefore he required the intervention of a propitiator, so that by having faith in him those who could not be justified by their own works might be justified. ${ }^{44}$

This excerpt of Origen comes from the oldest extant full commentary on Romans. It clarifies that Origen, whom Aulén cites as a proponent of the classic view, also advanced a view consistent with Anselm's. In this quotation about Romans 3:21-26, Origen explains that in achieving 'our redemption', Jesus became 'our propitiator'. The price he paid on behalf of sinners put them at peace with holy God, reconciling the 'unjust' to the 'just'. ${ }^{45}$ Propitiation here implies an object, someone who is conciliated by the act. Since Origen states that it is God who required the propitiator, it is likewise most plausible that God is the object of the propitiation. Thus, Origen here appears to explain that atonement is offered to God, by Christ, as man. Indeed, in that same commentary Origen clarifies that Christ is an effective mediator between God and humankind because of his true humanity:

The apostle, when discussing the mediator, indicated this by a plain distinction by saying, 'the mediator between God and men, the man Christ Jesus' [1 Timothy 2:5]; by which he was obviously teaching that 'mediator' must be referred not to Christ's deity but to his humanity. ${ }^{46}$

\footnotetext{
Justin's discourse, in which the primary dilemma he is addressing is precisely that the 'human race is under a curse'. Thus, when Justin says that 'no curse lies on the Christ of God', he is not necessarily rejecting the idea that Christ bore the curse in the stead of sinners; he is more likely articulating Christ's innocence, that Christ was not bearing a curse that he deserved.

43 Irenaeus (Against Heresies 5.1.2), Origen (Schol. in Cant., 2.17), Gregory of Nyssa (Eun. 4), Gregory of Nazianzus (Or. 29.20), Eusebius (Dem. ev., 10.1), Hilary of Poitiers (Hom. Ps. 53 (54)), Chrysostom (Comm. Gal. 3, Hom. Gal. 3:13).

44 Origen, Comentarii in Epistulam ad Romanos, vol. 2, ed. T. Heither (5 vols; New York: Herder, 1990-1995): 112, 130 (ACCS NT 6:99).

45 As with Irenaeus' use of 'propitiation', the context of this passage makes it unlikely that Origen is simply referring to expiatory sacrifice.

46 Origen, Commentary on the Epistle to the Romans, tr. Thomas P. Sheck (Washington: Catholic University of America, 2001): 219. Emphases added.
} 
Origen also does not here introduce the imagery of a victorious conflict with the powers of darkness. In this context, the obstacle to humanity's salvation instead seems to be the impossibility that human unrighteousness and God's righteousness could coexist in relationship, rather than captivity to the forces of evil. Thus, Origen explains the necessity of Christ as a human propitiator to justify humanity before God, a view consistent with satisfaction theories and not reducible to the classic view.

\section{b. Tertullian}

If the Father 'sent his Son in the likeness of sinful flesh' [Romans 8:3], it must not be said that the flesh in which he appeared was illusory ... the Son was sent in the likeness of sinful flesh in order to redeem our sinful flesh by a like substance, even a fleshly one, which bore a resemblance to sinful flesh although it was itself free from $\sin ^{47}$

Tertullian was the first prominent Father to write in Latin. Commenting on Romans $8: 3$, he argues that sinful flesh could only be bought back by the substitution of 'a like substance' which was 'itself free from sin', and only the Son of God himself in flesh could meet that requirement. In this, he unambiguously states the efficacy of Christ's human nature in making atonement for sin.

Moreover, Peter Ensor has examined Tertullian's corpus of writings and argues that he "bears witness ... to the understanding of the cross of Christ as a work of penal substitutionary atonement, and thereby to the existence of this understanding in the Church of his time'. ${ }^{48}$ Indeed, like Justin, Tertullian also explains atonement in terms of Deuteronomy $21: 23$ and Galatians 3:13. He teaches that the curse is death, and comes as God's punishment for sin: 'whoever, in any sin, had incurred the judgment of death, and died suspended on a tree, he should be "cursed by God". ${ }^{49}$ Therefore, Christ 'brought on himself the Creator's curse' 50 and 'was slain that we might not be slain'. ${ }^{51}$ In these terms, it is clear that Christ by his death spares humanity the divine consequence for sin and brings life.

\footnotetext{
47 Tertullian, Against Marcion 5.14 (ANF 3:459).

48 Peter Ensor, 'Tertullian and Penal Substitutionary Atonement', EvQ 86.2 (2014): 130-42, esp. 142.

49 Tertullian, Answer to the Jews 10 (ANF 3:164).

50 Tertullian, Against Marcion 1.11 (ANF, 3:279).

51 Tertullian, Scorpiace 1 (ANF, 3:634).
} 
Thus, Tertullian articulates the view that Christ's sinless human nature made him a satisfactory substitute for our redemption, which aligns with the wider Anselmian view. More specifically, he provides another early teaching that aligns with the essential tenets of penal substitution.

\subsection{Fourth Century}

\section{a. Cyril of Jerusalem}

Cyril was Bishop of Jerusalem in the mid-fourth century. His Catechetical Lectures, which he delivered to new believers to prepare them for baptism and communion, are his most significant work. The later lectures expound the articles of the creed that catechumens recited at baptism. One lecture, 'On the Words, Crucified and Buried', has particular significance for this discussion. Since Cyril addressed this lecture to catechumens, it provides clear insight into the beliefs that the early church held about the cross. Referring to Colossians 1:20 and 1 Peter 2:24, Cyril there says:

The Savior endured all this, 'making peace through the blood of the cross' ... For we were enemies of God through sin, and God had decreed the death of the sinner. One of two things, therefore, was necessary, either that God, in his truth, should destroy all men, or that in his loving-kindness, he should remit the sentence. But see the wisdom of God; he preserved the truth of his sentence and the exercise of his loving-kindness. Christ took our sins 'in his body upon the tree; that we, having died to sin,' by his death 'might live to justice.' He who died for us was of no small worth; he was no material sheep; he was no mere man. He was more than an angel, he was God made man. ${ }^{52}$

Cyril explains why the cross was necessary to reconcile sinful people with holy God. At creation no tension existed between God's love and his law; his love caused him to design everything good, and his law was meant to keep it good for those he loved. Yet when humanity transgressed, Cyril says, God faced a dilemma: how could his love and his law both remain true? If he dismissed the consequences of breaking the law, it would violate the truth of his word, allow error to increase unchecked, and undermine the meaningfulness of human free choice. (Indeed, if to obey and to disobey incur the same result, then actions matter little and the capacity for genuine relationship with God is

52 Cyril of Jerusalem, Catechetical Lectures 13.33 (ACCS NT 9:21). 
diminished.) Yet if God dismissed his concern for humanity and let it perish, then his love would be violated in equal measure.

Cyril explains how God severed the Gordian knot in the person and work of Jesus. To '[preserve] the truth of his sentence and the exercise of his loving-kindness', Christ 'took our sins' upon himself in death, in order that we might live new life. On the one hand, therefore, it was a self-giving act of love. Yet on the other hand, Christ's death as a man fulfilled the divinely decreed sentence, and the consequences of breaking God's law were not violated or rendered meaningless.

Notably, Cyril does not here refer to victory over Satan. The primary dilemma in view is the enmity between God and humanity caused by sin - 'we were enemies of God'. Cyril also articulates the significance of Christ's human nature to the work of reconciliation elsewhere in the lecture: '[Christ] stretched forth human hands ... and they were fastened with nails, that his manhood ... having been nailed to the tree, and having died, sin might die with it, and we might rise again in righteousness. ${ }^{53}$

Therefore, Cyril explains that Christ, moved by love, assumed human nature to fulfil God's sentence on $\sin$ in such a way that we might yet live. Christ's death was a plan of God, and yet presented something to God at the same time, satisfying both the requirement of his love and the requirement of his just law. This further demonstrates that satisfaction views of atonement have roots in the Fathers.

\section{b. Athanasius of Alexandria}

Athanasius played a central role in opposing the Arian heresy and protecting the orthodox view of Christ's nature. Regarding Philippians 2, a text that describes Christ's incarnation and purpose, he said:

The text says 'he humbled himself' with reference to the assumption of the flesh ... It was the human race that needed this, because of the humiliation of its flesh and of its consequent death. Thus the Word who is immortal and the image of the Father 'has taken the form of a slave' and suffered death on the cross as a man for our sake. He did this in order that he might thus present himself as an offering to the Father. It is thus as a man that he is said to have been exalted for our sake. Hence all of us die in Christ and through his death may again be exalted in Christ himself. ${ }^{54}$

Athanasius plainly states that Christ, as man, presented something to God that was necessary for atonement: 'as a man', Christ suffered death to

53 Cyril of Jerusalem, Catechetical Lectures $13.28\left(N P N F^{2}\right.$ 7:89).

54 Athanasius, Against the Arians 1.41 (ACCS NT 8:239). 
make 'an offering to the Father' on behalf of all people. Because of sin, we faced 'consequent death' except for such an innocent offering, as no sinful person could make an effective offering to God and live. This is a clear articulation of the distinguishing elements of Anselm's view. Athanasius therefore directly refutes Aulén's claim that the Anselmic view is not rooted in the early church, particularly in the East.

Moreover, in On the Incarnation Athanasius lays out the essential logic of penal substitution specifically, though he does not develop it into a full theory:

If any of our own people also inquire ... why he suffered death in none other way save on the Cross, let him also be told that no other way than this was good for us, and that it was well that the Lord suffered this for our sakes. For if he came himself to bear the curse laid upon us, how else could he have 'become a curse,' [Gal. 3:13] unless he received the death set for a curse? And that is the Cross. For this is exactly what is written: 'Cursed is he that hangeth on a tree.' [Deut. 21:23] Again, if the Lord's death is the ransom of all, and by his death 'the middle wall of partition' [Eph. 2:14] is broken down ... how would he have called us to him, had he not been crucified $?^{55}$

As we have seen, the Pauline language of the 'curse' is a basis for the penal element of atonement in the Fathers. This passage from Athanasius further substantiates that theme. Like Justin and Tertullian, it is clear that Athanasius regards 'the death set for a curse' as tantamount to divine punishment for sin. Further, Christ came to 'bear the curse laid upon us' and so 'suffered this for our sakes' in order that that we would not have to, and that he might 'call us to him[self]' to live in reconciled relationship with God and others.

The use of this Pauline imagery also informs what he means by the image of 'ransom' in this context. As in Diognetus, the context suggests that 'ransom' conveys the idea that Christ's death as a man paid the punishment God set for human disobedience. Though the devil is mentioned later in the chapter, he is not there regarded as a recipient of the ransom, but as a deceiver who 'tries to hinder them that are going up [to heaven]'. ${ }^{56}$

Therefore, Athanasius did not exclusively understand the atonement in terms of Aulén's classic view. At minimum, the views Athanasius expresses here parallel Anselm's wider tradition, while the latter passage

55 Athanasius, On the Incarnation of the Word 25.1-3 (NPNF² 4:49).

56 Athanasius, On the Incarnation of the Word 25.5 (NPNF² 4:49). 
articulates the essential logic of the penal substitutionary view specifically.

\section{c. John Chrysostom}

Chrysostom was Archbishop of Constantinople from AD 398-403 and was famous in the early Eastern church for his preaching. His sermons therefore provide valuable insight into the common and accepted doctrines of his era, and the quotations below confirm that he too maintained a view of the cross consistent with the Anselmic tradition. ${ }^{57}$

God allowed his Son to suffer as if a condemned sinner, so that we might be delivered from the penalty of our sins. This is God's righteousness, that we are not justified by works (for then we would have to be perfect, which is impossible), but by grace, in which case all our sin is removed. ${ }^{58}$

If one that was himself a king, beholding a robber and malefactor under punishment, gave his well-loved son, his only-begotten and true, to be slain; and transferred the death and the guilt as well, from him to his son (who was himself of no such character), that he might both save the condemned man and clear him from his evil reputation; and then if, having subsequently promoted him to great dignity, he had yet, after thus saving him and advancing him to that glory unspeakable, been outraged by the person that had received such treatment: would not that man, if he had any sense, have chosen ten thousand deaths rather than appear guilty of so great ingratitude ${ }^{59}$

In both of these passages Chrysostom emphasises that the innocent Son suffered on behalf of the guilty. Christ became man to 'transfer' the totality of our sin to himself and bear its full 'punishment' in our place 'as if a condemned sinner' in order to 'deliver [us] from the penalty of our sins'. This imagery also underscores the importance of Christ's human nature to the achievement of this substitution. Because of sin, all people were guilty before God, and yet no one could endure the punishment he required and live. Jesus therefore died so that a man indeed paid for sin, and yet God paid for man. Moreover, Chrysostom teaches that the cross reveals 'God's righteousness' - the death of Jesus was not arbitrary, but a manifestation of both God's love and his holiness in equal measure. Thus, the view Chrysostom articulates in these passages is consistent with the broader Anselmic view, but also with the

57 See Hom. Rom. 9, Hom. Gal. 3:13, Comm. Gal. 3, Hom. Col. 6, and Baptismal Instructions 3.21.

58 John Chrysostom, Hom. 2 Cor. 11.5 (ACCS NT 7:249).

59 John Chrysostom, Hom. 2 Cor. $11.6\left(N P N F^{l}\right.$ 12:335). 
essential tenets of penal substitution specifically. ${ }^{60}$ Chrysostom is yet another Father who refutes Aulén's historical claims.

\section{d. Theodore of Heraclea}

He bore the sum of human evils and every form of transgression, as well as their recompense and punishment. And as if he were our debtor, the only-begotten Word of God, coming into the world alongside us, fulfilled every law and all righteousness and did not stumble over sin but received it willingly so as to change our punishment into peace and harmony ${ }^{61}$

Little is known about Theodore's life, though the Orthodox tradition holds that he was martyred by Licinius, Constantine's predecessor. The above quotation provides his exegesis of Isaiah 53, in which he articulates a view of Christ's atoning work that is not only consistent with Anselm's general approach, but the essential tenets of penal substitution specifically. Theodore identifies Jesus as the fulfilment of the Suffering Servant prophecy, the one who would 'change our punishment into peace' with God by 'bearing the sum of human evils and every form of transgression, as well as their recompense and punishment'. It is clear that Theodore believes Christ suffered as a man on behalf of all people ('coming alongside us'); he 'bore the sum of human evils', a burden that we could not bear ourselves, yet without which right relationship with God was impossible. And he explains this without reference to a conflict with the powers of darkness. This refutes Aulén's claim that the Fathers did not believe Christ's human nature was efficacious for atonement by satisfying God's requirements, and the claim that the classic view was the only understanding of atonement in the early church.

\section{e. Ambrose of Milan}

Jesus took flesh that he might destroy the curse of sinful flesh, and he became for us a curse that a blessing might overwhelm a curse, uprightness might overwhelm sin, forgiveness might overwhelm the sentence, and life might overwhelm death. He also took up death that the sentence might be fulfilled and satisfaction might be given for the judgment, the curse placed on sinful flesh even to death. Therefore, nothing was done contrary to God's sentence when the terms of that sentence were fulfilled, for the curse was unto death but grace is after death. ${ }^{62}$

60 See also Homilies on 1 Timothy $7.7\left(N P N F^{1}\right.$ 12:334).

61 Theodore of Heraclea, Fragments on Isaiah, PG 18:1356c-d (ACCS OT 11:164).

${ }^{62}$ Ambrose of Milan, Flight from the World in The Fathers of the Church, vol. 65, tr. M. P. McHugh (Washington: Catholic University of America Press, 1972): ch. 7, sect. 44, 314-15. 
Ambrose was Bishop of Milan, a staunch critic of Arianism and a mentor to Augustine. Here he gives a straightforward interpretation of the 'curse' imagery of Galatians 3:13 that is not reducible to the classic view. When Christ 'became for us a curse' and died on the cross, it was so that God's 'sentence might be fulfilled' against human sin. He thus emphasises that Christ died on behalf of sinners; his work as a man accomplished 'satisfaction' for God's judgement on human sin, something humanity could not do for itself. Moreover, Christ's work in human flesh was the only way that 'forgiveness might overwhelm the sentence' and yet nothing would be done 'contrary to God's sentence'. In other words, Christ's death presented something to God that satisfied his righteous requirements. Therefore, Ambrose also clearly shows that Anselm's view has roots in the Fathers.

\subsection{Fifth Century}

\section{a. Theodoret of Cyrrhus}

Theodoret is notable for his seemingly comprehensive knowledge of the Fathers who preceded him; Eranistes contains 238 separate texts from 88 works of his predecessors, including Ignatius, Irenaeus, Hippolytus, Athanasius, and others. ${ }^{63}$ It is apparent that Theodoret was concerned with the agreement of his own teaching with those who preceded him. $\mathrm{He}$ is therefore a qualified witness to the prevailing beliefs of the early church.

When the high priest approached [the mercy seat], the holy kindness of God was revealed. The apostle teaches us that Christ is the true mercy seat, of which the one in the Old Testament was but a type. The name applies to Christ in his humanity, not in his divinity. For as God, Christ responded to the expiation made at the mercy seat. It is as man that he receives this label, just as elsewhere he is called a sheep, a lamb, sin and a curse ... the Lord Christ is both God and the mercy seat, both the priest and the lamb, and he performed the work of our salvation by his blood, demanding only faith from us. ${ }^{64}$

The above excerpt is Theodoret's interpretation of Romans 3:21-25 and the i $\lambda \alpha \sigma \tau$ ๆ́p of Israel's atonement rites, and of which Christ is the fulfilment. In the

63 Andrew Louth, 'John Chrysostom to Theodoret of Cyrrhus' in The Cambridge History of Early Christian Literature, ed. Frances Young, Lewis Ayres, and Andrew Young (Cambridge: CUP, 2010): 350.

64 Theodoret of Cyr, Interpretatio epistole ad Romanos, PG 82:84d-85a (ACCS NT 6:102). 
Pentateuch, the mercy seat was a locus dei-a place where God met the Israelites on the Day of Atonement (Exod. 25:22). There, relationship with God was made right by blood offerings (Lev. 16), offered by the people and for the sins of the people. It is precisely this human offering at the mercy seat that Theodoret perceives Jesus fulfilled. Just as the mercy seat presented a human offering to God for atonement, so Christ, in assuming authentic humanity, presented an offering to God on behalf of all humanity to restore relationship.

Moreover, this commentary reveals that Theodoret interpreted other key atonement passages similarly. He likens this name for Christ, the true 'mercy seat', to other images in Scripture about him: a sheep (Isa. 53:7), a lamb (Isa. 53:7; John 1:29), sin (2 Cor. 5:21), and a curse (Gal. 3:13). Theodoret's understanding of the cross - that Jesus's vicarious death as a man presented an offering to God for reconciliation - was characteristic of early Christian atonement theories. ${ }^{65}$ This further undermines Aulén's claim that Christus Victor was the only prominent theory of atonement in the Fathers. Indeed, Theodoret's view clearly expresses the essential elements of satisfaction theory.

\section{b. Cyril of Alexandria}

Cyril was Patriarch of Alexandria in the early fifth century and played a significant role in denouncing Nestorianism as a heresy about the nature of Christ. Regarding Isaiah 53, he says:

The Only-begotten was made man, bore a body by nature at enmity with death, and became flesh, so that, enduring the death which was hanging over us as the result of our sin, he might abolish sin; and further, that he might put an end to the accusations of Satan, inasmuch as we have paid in Christ himself the penalties for the charges of sin against us: 'For he bore our sins, and was wounded because of us. ${ }^{66}$

Cyril states the significance of Christ's human nature for atonement in a different way from the other Fathers we have examined. Because of Christ's vicarious suffering, he says, "we have paid in Christ himself the penalties for the charges of sin against us'. By this Cyril means that faith in Christ unites us with him, such that his payment is our own too. Yet this expression only makes sense if Christ's human nature is efficacious

\footnotetext{
65 See also Comm. Isa. 17.53.3-4, Prov. 10.26.

${ }^{66}$ Cyril of Alexandria, De adoratione et cultu in spirit et veritate, iii, 100; PG 293d296a (English tr. from Garry J. Williams, 'A Critical Exposition of Hugo Grotius's Doctrine of the Atonement in De Satisfactione Christi' (unpub. doctoral thesis, University of Oxford, 1999).)
} 
for atonement. Indeed, it implies that human sins necessitated a human payment to God for reconciliation to happen, a distinguishing tenet of the Anselmic tradition. Furthermore, Cyril outlines the thought of penal substitutionary atonement in the specific sense, whereby Christ endured the 'penalties' for $\sin$ - 'the death which was hanging over us' - in our place.

Moreover, it is significant to note the role Satan plays in this quotation. Though he is described as an 'accuser' pointing out peoples' failures to keep God's law, he is not described as the captor of humanity. All of this together confirms that Cyril's view cannot be characterised as an expression of the classic view, but further evidence that Anselm's general view, and indeed penal substitution specifically, have their roots in the teachings of the early church.

\section{c. Augustine of Hippo}

Augustine was perhaps the most influential theologian of the patristic period, producing the greatest number of surviving works of any Christian writer of that era. It is surprising, therefore, that Aulén says relatively little about Augustine and does not deal directly with his writings. Aulén offers only generalisations about his thought: '[Augustine] speaks with more emphasis than the generality of the Greek theologians of the judgment of God impending upon mankind, but he does not on this account incline to a Latin doctrine of the atonement ${ }^{\prime}{ }^{67}$ because to Augustine '[atonement] is one divine work, the continuity of which is not interrupted by the idea of an offering made to God from man's side, from below'. ${ }^{68}$

Aulén is correct that God's judgement on sin is a recurrent theme in Augustine's thinking about atonement. He is incorrect, however, that Augustine rejects the so-called 'Latin' tradition in so doing. The following passages from Augustine evince both (a) his view that Christ's death as a man fulfilled God's requirements regarding human sin, which agrees with the general tradition of Anselm, and (b) his view that Christ suffered the divinely sanctioned penalty for sin instead of us, which expresses the essential logic of penal substitution specifically. Consider, for example, this passage from Augustine's Reply to Faustus the Manichaean:

67 Aulén, Christus Victor, 58.

68 Aulén, Christus Victor, 46. 
If we read, 'Cursed of God is everyone that hangeth on a tree, ${ }^{99}$ the addition of the words 'of God' creates no difficulty. For had God not hated sin and our death, he would not have sent his Son to bear and abolish it ... But as Christ endured death as a man, and for man; so also, Son of God as he was, ever living in his own righteousness, but dying for our offences, he submitted as man, and for man, to bear the curse which accompanies death. ${ }^{70}$

While discussing Galatians 3, Augustine emphasises that Christ died 'as a man, and for man' and specifically that he died 'for our offences', though he was innocent. Moreover, Augustine provides a reason that atonement happened in this way: God 'hated sin and our death'. In other words, Christ's death as an innocent man was uniquely sufficient to address God's posture towards human sin and fulfil the 'curse' he levied against it - his commitment to destroy it.

This teaching indeed comports with the wider Anselmian tradition; atonement is made by Christ as man, who fulfils God's requirement by bearing the curse on sin that he put in place. Yet it also conveys the essential reasoning, though not a fully developed theory, of penal substitution in the specific sense. Like several other Fathers who treat the Pauline language of the 'curse' as a penal concept, Augustine shows that 'the curse which accompanies death' hung over human beings as a divinely set consequence of their 'offences' - effectively, a punishment or penalty. Augustine also affirms that Christ, in response to this curse, 'submitted' himself in place of sinners to the punishment of death associated with the curse, thus sparing them from it.

There is abundant evidence in other works that Augustine regarded sin as an offence that warranted divine punishment, and the cross as the means by which Christ bore this punishment in our place. For instance, he writes:

[The] one and only mediator between God and man, the man Christ Jesus, who condescended to undergo death - that is, the penalty of $\sin$ - without sin, for us ... he alone, on our behalf, undertook punishment without ill deservings, that we through him might obtain grace without good deservings. ${ }^{71}$

69 Gal. 3:13; cf. Deut. 21:23.

70 Augustine, Reply to Faustus the Manichaean 6 (NPNF² 4:209).

71 Augustine, Against Two Letters of the Pelagians 4.6 (NPNF 1 5:1159). See Enchiridion 33 ( $N P N F^{l}$ 3:515), Psalm LI (NPNFl 8:394-95), Against Faustus 14.3-4, 14.6-7 (NPNFl 4:208-209). 
Clearly, Augustine held the view that Christ accepted, on behalf of humankind, the punishment due to it in order to satisfy the divine requirement. Thus, his view of atonement comports well with both the Anselmic tradition in general and the framework of penal substitution specifically.

Moreover, Augustine held this view while also affirming that Jesus's work on the cross established him as a victor over sin and death. As he explained in the Confessions:

How you loved us, O good Father, who spared not even your only Son, but gave him up for us evil-doers! ... Alone of all, he was free among the dead, for he had power to lay down his life and power to retrieve it. For our sake he stood to you as both victor and victim, and victor because victim; for us he stood to you as priest and sacrifice, and priest because sacrifice, making us your children instead of your servants by being born of you in order to serve us. ${ }^{72}$

Here Augustine clearly affirms the classic view, but unlike Aulén he does not present it as an alternative to the Latin view. Indeed, Augustine shows a complementarity between these two theories of atonement. Christ, he says, was truly a 'victor'; he was 'free among the dead' with unique 'power to retrieve' his life. Yet he was also a 'victim', 'for our sake', who offered himself as a 'sacrifice' to God, just as the priests in ancient Israel made animal offerings to God for the sin of the people. Moreover, Augustine asserts that Christ was a victor because he was a victim. That is, because Christ submitted himself to death as an innocent man, his sacrifice achieved what no other human death could: it satisfied God's righteous requirements and reconciled us to him, 'making us', as Augustine put it in addressing God, 'your children'. Thus, for Augustine, Christ's victory was achieved precisely because God's righteous requirements were fulfilled by a blameless victim.

\section{Conclusion}

According to Aulén, the Latin view was virtually absent in the early church. He argues that the Fathers did not regard Christ's work on the cross as an offering made to God, but rather that they saw the cross as God's own work to defeat the evil powers that enslaved humanity.

72 Augustine, Confessions 10.43.69, tr. Maria Boulding, OSB (Hyde Park: New City Press, 1997): 282-83. 
As we have now seen, there are far too many texts that contradict these assertions to accept Aulén's conclusion. I have cited fifteen Fathers who span the first to the fifth century, from both East and West, who write in both Greek and Latin, who routinely affirm key aspects of satisfaction theories of atonement. Alongside the classic view, the Fathers explain that Jesus's death on behalf of sinners made atonement by presenting himself as a blameless offering to God in order to satisfy his justice. They repeatedly show how Christ's human nature made his suffering effective for this reconciliation - that he accomplished something as a man that no sinful person could accomplish for himself or herself. Moreover, the Fathers frequently do this without intermingling imagery of the victorious conflict with Satan, confirming that these teachings are not reducible to the classic view. Anselm's general view is firmly rooted in patristic literature; it is one of many understandings of the atonement with roots in that period. Aulén's argument therefore fails as a historical critique of Anselm's wider view, which likewise renders it unreliable as a critique of penal substitution more narrowly. Indeed, several Fathers I have cited here articulate the essential logic, though not necessarily the full theory, of penal substitution.

Moreover, as Augustine's work in particular evinces, many Fathers advanced satisfaction theories and Christus Victor as complementary and not mutually exclusive. The Fathers acknowledged that the different aspects of atonement simply articulated different purposes that Christ's death accomplished; the cross was both a work of God and an offering to God. Aulén's reductionist exegesis of the Fathers therefore produces an unnecessarily impoverished account of the atonement. He fails to see how the Latin and classic views are complementary.

Indeed, viewing these two aspects of the atonement as complementary creates no logical tension. They form a natural synthesis that provides a more comprehensive account of the cross. The Fathers attest that the cross eliminated two impediments to salvation that humanity faced because of its sin: enmity with God and bondage to Satan. These dilemmas are indeed related. Humanity's bondage to Satan was a consequence of the sin that also produced its enmity with God. Indeed, if humanity's relationship with God had not first been fractured, if men and women were not already under divine judgement, then they would not be liable to Satan's accusations or subject to his dominion. In other words, without sin there would be no enmity or captivity; conversely, without sacrifice there would be no reconciliation or victory. Christ is 
victorious precisely because his sacrificial death on behalf of men and women mended the relationship between God and humankind. Thus, the patristic tradition regarding the atonement provides a richer understanding than Aulén's account allows. 